\title{
Parasites in farmed Piaractus brachypomus (Serrasalmidae) in the state of Acre, western Brazilian Amazonia
}

\author{
Luciano Pereira NEGREIROS ${ }^{1}$, Marcos TAVARES-DIAS ${ }^{2 *}$ (b \\ 1 Instituto Federal de Educação, Ciências e Tecnologia do Acre (IFAC), Rio Branco, AC, Brasil \\ 2 Embrapa Amapá, Rodovia Juscelino Kubitschek, km 5, 2600, Universidade, 68903-419, Macapá, AP, Brasil \\ * Corresponding author: marcos.tavares@embrapa.br; iDttps://orcid.org/0000-0002-8376-1846
}

\begin{abstract}
This study investigated the parasite fauna in Piaractus brachypomus grown in fish farms in the state of Acre, in the western Brazilian Amazon. We examined 160 fish from four farms. Overall parasite prevalence was 66.9\%. The fish were parasitized by Anacanthorus spathulatus, Mymarothecium viatorum, Anacanthorus penilabiatus, Clinostomum marginatum, Echinorhynchus jucundus and Henneguya sp., but monogenean species were the dominant parasites. Monogeneans showed an aggregated distribution pattern and there was a weak correlation between host size and abundance of M. viatorum and A. penilabiatus. No difference in the condition factor of parasitized and non-parasitized fish was detected. The fish of all farms had the gills parasitized by $A$. spathulatus and $M$. viatorum, but $A$. penilabiatus was found only in fish from two farms. Echinorhynchus jucundus, C. marginatum and Henneguya sp. were found in only one farm. The differences in parasitism level among the farms are attributable to differences in management and quality of cultivation environments.
\end{abstract}

KEYWORDS: fish farming, Monogenea, endoparasites, pirapitinga

\section{Parasitos de Piaractus brachypomus (Serrasalmidae) cultivado no estado do Acre, Amazônia ocidental brasileira}

\section{RESUMO}

Este estudo investigou a fauna de parasitos em Piaractus brachypomus cultivados em pisciculturas do estado do Acre, na Amazônia ocidental brasileira. Examinamos 160 peixes de quatro pisciculturas. A prevalência geral de parasitos foi de 66,9\%. Os peixes estavam parasitados por Anacanthorus penilabiatus, Anacanthorus spathulatus, Mymarothecium viatorum, Clinostomum marginatum, Echinorhynchus jucundus e Henneguya sp., mas a dominância foi de espécies de Monogenea. Os parasitos monogeneas apresentaram padrão de distribuição agregado e houve fraca correlação do tamanho dos hospedeiros com a abundância de $M$. viatorum e $A$. penilabiatus. Não houve diferença no fator de condição de peixes parasitados e não parasitados. Os peixes de todas as pisciculturas tiveram as brânquias parasitadas por $A$. spathulatus e $M$. viatorum, mas $A$. penilabiatus foi encontrado somente nas brânquias dos peixes de duas pisciculturas. Echinorhynchus jucundus, C. marginatum e Henneguya sp. foram encontrados em apenas uma piscicultura. As diferenças no nível de parasitismo entre as pisciculturas são atribuíveis a diferenças no manejo e qualidade dos ambientes de cultivo.

PALAVRAS-CHAVE: piscicultura, Monogenea, endoparasitos, pirapitinga

\section{INTRODUCTION}

Aquaculture production is increasingly being considered as an answer to food security issues worldwide (FAO 2018). In Brazil, fish farming turned into an economic activity in the 1990s, with the emergence and dissemination of management technologies aimed at the cultivation of native species, and the first large-scale fish farms began the fattening of these fish (Kubitza 2007; Franceschini et al. 2013). Currently, one of the farmed fish species with greatest potential in Brazil is Piaractus brachypomus Cuvier, 181 (Serrasalmidae), locally known as pirapitinga (Cruz et al. 2006; Franceschini et al. 2013; Ribeiro et al. 2016; Saint-Paul 2017).

Piaractus brachypomus is the third largest scale fish from the Amazon basin, reaching up to $0.8 \mathrm{~m}$ in length and about $20 \mathrm{~kg}$ in weight. It presents attractive body characteristics for the consumer market, such as small head size, ease of flaking, as well as advantages for farming, such as rapid growth, resistance to high water temperatures and low levels of dissolved oxygen, and resistance to handling and diseases (Ribeiro et al. 2016). The species is economically important and increasingly produced in fish farms in the state of Acre, 
in the western Brazilian Amazon region. In 2018, fish farming in Acre increased 6.5\% relative to 2017 and produced 8,500 tons of fish, of which $98 \%$ corresponded to native species, and occupying the $19^{\text {th }}$ position among 27 Brazilian states (PeixesBR 2019).

In intensive fish culture, parasitic infections can be limiting factors for production and productivity, resulting in economic losses and/or expenses with antiparasitic treatments (Silva et al. 2013; Dias et al. 2015; Tavares-Dias and Martins 2017). Parasitic infections are favored by poor water quality and inadequate farming management and can compromise the defense mechanism of the fish, which in turn can lead to epizooties; in addition, the high stocking densities used in intensive fish farming can potentiate the effect of parasitism (Morais et al. 2009; Santos et al. 2013; Silva et al. 2013; Franceschini et al. 2013; Dias et al. 2015). Piaractus brachypomus farmed in Colombia were found to be parasitized in the gills by undetermined monogeneans and myxosporeans, Piscinoodinium pillulare, Ichthyophthirius multifiliis and Trichodina sp. (Verján et al. 2001). There is no other information on the parasite fauna in P. brachypomus from cultivation systems.

Thus, considering the importance of $P$. brachypomus in fish farming in the western Amazon region, and the lack of knowledge on its parasites, the objective of the present study was to determine the parasites of P. brachypomus in fish farms in the state of Acre and relate the presence of parasites with cultivation conditions.

\section{MATERIAL AND METHODS}

Piaractus brachypomus were sampled for parasitological analysis in fish farms in the municipality of Rio Branco, state of Acre (Brazil). The climate in state of Acre is of the humid equatorial type, with mean air temperature between 22 and $26^{\circ} \mathrm{C}$, and varying rainfall levels throughout the year. Most fish farms in Acre use natural water bodies (rivers or streams) as direct water source to supply their tanks.
We sampled four fish farms between June 2015 and May 2016. In each farm, 40 specimens of P. brachypomus (total $\mathrm{N}=$ 160) were collected from two earth tanks (20 fish per tank). The farms varied in management and infrastructure characteristics, i.e. fish size, stocking density, sanitary quality (Table 1) and water supply source. During the collection of fish, the water $\mathrm{pH}$ was determined using a digital $\mathrm{pH}$ meter $(\mathrm{pH} 100, \mathrm{YSI}$, USA), as well as temperature and dissolved oxygen levels, using a digital oximeter (DO, YSI, USA). This study was approved by the Ethics Committee for Animal Use of Embrapa Amapá (Protocol No 002/2016, CEUA-CPAFAP).

The weight $(\mathrm{g})$ and length $(\mathrm{cm})$ of each fish was measured. During the necropsy, the mouth, operculum, gills, gastrointestinal tract and viscera were inspected for parasites. The gills were removed, fixed in 5\% formalin and analyzed under a stereomicroscope (Nikon SMZ800N, Tokyo, Japan) and a microscope (Eclipse E100, Nikon, Tokyo, Japan). The gastrointestinal tract and viscera of the fish were removed and examined under a stereomicroscope to collect endoparasites. The methodology used for collecting, fixing, counting and preparing parasites for identification followed Eiras et al. (2006) and Boeger and Viana (2006).

The ecological parameters estimated followed Bush et al. (1997). The dominance frequency (percentage of infracommunities in which a parasite species is numerically dominant) was determined according to Rohde et al. (1995). The dispersion index (DI) and discrepancy index (D) were calculated for species with prevalence $>10 \%$ using the software Quantitative Parasitology 3.0, in order to detect the distribution pattern of parasite infracommunities (Rózsa $e t$ al. 2000). The significance of DI, for each infracommunity, was tested using the $d$-statistics (Ludwig and Reynolds 1988).

Weight and total length data of the fish examined were used to calculate the relative condition factor $(\mathrm{Kn})$ of parasitized and non-parasitized fish (Le Cren 1951), which were compared using the $t$-test. The Spearman correlation coefficient $(r s)$ was applied to determine possible correlations of length and weight with the abundance of parasites (Zar 2010).

Table 1. Geographical coordinates of the four fish farms sampled for parasitological analysis of Piaractus brachypomus in the state of Acre (western Brazilian Amazonia). Size and parameters of water quality of the sampled tanks are shown, and sample size, average body parameters, stocking density and prevalence of parasites in $P$. brachypomus analyzed in each farm. DO = dissolved oxygen, $\mathrm{N}=$ number of fish sampled. Values are the mean \pm SD (from four measurements from two tanks at each farm for water parameters).

\begin{tabular}{|c|c|c|c|c|c|c|c|c|c|c|}
\hline Farm & Geographical coordinates & $\begin{array}{c}\text { Tank size } \\
\left(\mathrm{m}^{3}\right)\end{array}$ & $\begin{array}{c}\mathrm{DO} \\
\left(\mathrm{mg} \mathrm{L}^{-1}\right) \\
\end{array}$ & $\mathrm{pH}$ & $\begin{array}{c}\text { Temperature } \\
\left({ }^{\circ} \mathrm{C}\right)\end{array}$ & N & $\begin{array}{l}\text { Weight } \\
\text { (g) }\end{array}$ & $\begin{array}{l}\text { Length } \\
(\mathrm{cm})\end{array}$ & 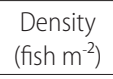 & $\begin{array}{c}\text { Prevalence } \\
(\%)\end{array}$ \\
\hline 1 & $9^{\circ} 55^{\prime} 05.70^{\prime \prime} \mathrm{S}, 67^{\circ} 47^{\prime} 01.46^{\prime \prime} \mathrm{W}$ & 1800 & $5.3 \pm 1.1$ & $7.7 \pm 1.2$ & $28.3 \pm 1.2$ & 40 & $16.1 \pm 14.5$ & $7.1 \pm 1.6$ & 2.0 & 25.0 \\
\hline 2 & $10^{\circ} 03^{\prime} 11.28^{\prime \prime} \mathrm{S}, 67^{\circ} 50^{\prime} 41.47^{\prime \prime} \mathrm{W}$ & 1800 & $2.3 \pm 1.3$ & $5.6 \pm 1.2$ & $30.1 \pm 1.1$ & 40 & $113.9 \pm 81.2$ & $12.8 \pm 3.8$ & 2.9 & 85.0 \\
\hline 3 & $9^{\circ} 45^{\prime} 24.5^{\prime \prime} \mathrm{S}, 68^{\circ} 04^{\prime} 25.0^{\prime \prime} \mathrm{W}$ & 800 & $1.4 \pm 1.1$ & $5.1 \pm 1.1$ & $29.2 \pm 1.3$ & 40 & $13.6 \pm 4.7$ & $6.9 \pm 0.9$ & 3.2 & 80.0 \\
\hline 4 & $9^{\circ} 02^{\prime} 53.71^{\prime \prime} \mathrm{S}, 68^{\circ} 37^{\prime} 44.69^{\prime \prime} \mathrm{W}$ & 800 & $2.8 \pm 2.0$ & $5.9 \pm 0.6$ & $28.1 \pm 1.0$ & 40 & $758.7 \pm 363.5$ & $26.5 \pm 4.4$ & 2.8 & 77.5 \\
\hline
\end{tabular}




\section{RESULTS}

Dissolved oxygen level was below minimum acceptable values in three farms (Table 1). The body size of the sampled specimens of $P$. brachypomus varied among farms, as they were in different stages of culture (fingerlings and fattening). Thus, total parasite prevalence varied among farms, and was lower in the farm with lower stocking density of fishes (Table 1).

In all farms, the gills of the fish were parasitized by Anacanthorus spathulatus Kritsky, Thatcher \& Kayton 1979 and Mymarothecium viatorum Boeger Piasecki \& Sobecka 2002 (Dactylogyridae). Anacanthorus penilabiatus Boeger, Husak \& Martins 995 (Dactylogyridae) was found only in the gills of fish from farms 2 and 3 (see Table 1 for farm codes and characteristics), while Echinorhynchus jucundus Travassos 1923 (Echinorhynchidae) and metacercariae of Clinostomum marginatum Rudolphi, 1819 (Clinostomidae) occurred only in the gills of fish from farm 3. Cysts of Henneguya sp. (Myxosporea) were found only in gills of fish from farm 2 (Table 2). Overall, the prevalence of parasites was $66.9 \%, M$. viatorum and $A$. spathulatus were the dominant species, and the parasites presented an aggregated dispersion pattern (Table 3).
The abundance of $A$. spathulatus showed no correlation with total length $(r s=0.06, \mathrm{p}=0.45)$ and body weight $(r s=$ $0.05, \mathrm{p}=0.52$ ) of the hosts. A weak negative correlation of $A$. penilabiatus abundance with the length $(r s=0.29, \mathrm{p}=0.0002)$ and weight $(r s=-0.28, \mathrm{p}=0.0003)$ of the host was observed. There was a weak positive correlation of the abundance of $M$. viatorum with the length $(r s=0.28, \mathrm{p}=0.0006)$ and weight $(r s=-0.27, \mathrm{p}=0.0006)$. There was no significant difference $(\mathrm{t}$-test $=1.11 ; \mathrm{p}=0.26)$ in the relative condition factor $(\mathrm{Kn})$ between parasitized $(\mathrm{Kn}=0.99 \pm 0.04)$ and non-parasitized fish $(\mathrm{Kn}=0.99 \pm 0.08)$.

\section{DISCUSSION}

In hybrid Colossoma macropomum x Piaractus brachypomus from the eastern Amazon, parasitic prevalence was 63.1\% (Dias et al. 2015). In this study, the overall parasitic prevalence was $66.9 \%$, lower than that reported by Verján et al. (2001), for $P$. brachypomus cultured in Colombia (100\%). However, Verján et al. (2001) examined only fingerlings, while we examined fish in the fattening phase and fingerlings. In three of the fish farms, there were low levels of dissolved oxygen in the water, high stocking density of fish when compared to fish

Table 2. Parasites in Piaractus brachypomus from four fish farms in the state of Acre (western Brazilian Amazon). P: Prevalence, MI: Mean intensity, MA: Mean abundance. $\mathrm{N}=40$ for each farm. Values are the mean \pm SD.

\begin{tabular}{|c|c|c|c|c|c|c|c|c|c|c|c|c|}
\hline \multirow{2}{*}{ Parasite species } & \multicolumn{3}{|c|}{ Farm 1} & \multicolumn{3}{|c|}{ Farm 2} & \multicolumn{3}{|c|}{ Farm 3} & \multicolumn{3}{|c|}{ Farm 4} \\
\hline & $\mathrm{P}(\%)$ & $\mathrm{Ml}$ & $M A \pm S D$ & $\mathrm{P}(\%)$ & $\mathrm{Ml}$ & $M A \pm S D$ & $\mathrm{P}(\%)$ & $\mathrm{Ml}$ & $M A \pm S D$ & $\mathrm{P}(\%)$ & $\mathrm{Ml}$ & $M A \pm S D$ \\
\hline \multicolumn{13}{|l|}{ Monogenea } \\
\hline Anacanthorus spathulatus & 22.5 & 2.4 & $0.5 \pm 1.1$ & 77.5 & 11.9 & $9.3 \pm 10.9$ & 72.5 & 28.1 & $20.4 \pm 22.5$ & 50.0 & 6.5 & $3.3 \pm 8.4$ \\
\hline Anacanthorus penilabiatus & 0 & 0 & 0 & 22.5 & 1.7 & $0.4 \pm 1.6$ & 72.5 & 16.5 & $11.9 \pm 12.9$ & 0 & 0 & 0 \\
\hline Mymarothecium viatorum & 15.0 & 5.2 & $0.8 \pm 2.8$ & 77.5 & 14.7 & $11.4 \pm 13.9$ & 77.5 & 20.7 & $16.0 \pm 20.7$ & 72.5 & 13.4 & $9.7 \pm 13.5$ \\
\hline \multicolumn{13}{|l|}{ Digenea } \\
\hline Clinostomum marginatum & 0 & 0 & 0 & 0 & 0 & 0 & 2.5 & 1.0 & $0.02 \pm 0.02$ & 0 & 0 & 0 \\
\hline \multicolumn{13}{|l|}{ Acanthocephala } \\
\hline Echinorhynchus jucundus & 0 & 0 & 0 & 0 & 0 & 0 & 12.5 & 1.4 & $0.2 \pm 0.02$ & 0 & 0 & 0 \\
\hline \multicolumn{13}{|l|}{ Myxozoa } \\
\hline Henneguya sp. & 0 & 0 & 0 & 47.7 & - & - & 0 & 0 & 0 & 0 & 0 & 0 \\
\hline
\end{tabular}

Table 3. Parasites in Piaractus brachypomus ( $N=160)$ of four fish farms in the state of Acre, in the western Brazilian Amazon. Sl: site of infection, EF: examined fish, PF: parasitized fish, DI: dispersion index, d: statistic-d, D: discrepancy, P: prevalence, MA: mean abundance, MI: mean intensity. Values are the mean \pm SD.

\begin{tabular}{|c|c|c|c|c|c|c|c|c|}
\hline Parasite species & $\mathrm{SI}$ & $\mathrm{P}(\%)$ & $\mathrm{Ml}$ & $M A \pm S D$ & $\mathrm{FD}(\%)$ & $\mathrm{DI}$ & $d$ & $\mathrm{D}$ \\
\hline \multicolumn{9}{|l|}{ Monogenea } \\
\hline Anacanthorus spathulatus & Gills & 55.6 & 15.0 & $8.4 \pm 15.1$ & 0.40 & 5.640 & 34.5 & 0.630 \\
\hline Anacanthorus penilabiatus & Gills & 23.8 & 13.0 & $3.1 \pm 8.4$ & 0.15 & 3.658 & 26.3 & 0.825 \\
\hline Mymarothecium viatorum & Gills & 60.0 & 15.8 & $9.5 \pm 14.8$ & 0.45 & 5.902 & 35.5 & 0.614 \\
\hline \multicolumn{9}{|l|}{ Digenea } \\
\hline Clinostomum marginatum & Gills & 0.6 & 1.0 & $0.01 \pm 1.0$ & - & - & - & - \\
\hline \multicolumn{9}{|l|}{ Acanthocephala } \\
\hline Echinorhynchus jucundus & Intestine & 3.1 & 1.4 & $0.04 \pm 0.3$ & - & - & - & - \\
\hline \multicolumn{9}{|l|}{ Myxozoa } \\
\hline Henneguya sp. & Gills & 11.9 & - & - & - & - & - & - \\
\hline
\end{tabular}


farm 1, which favored the prevalence of parasites. In none of the farms the fish presented external signs of disease, which indicates the resistance to diseases of farmed $P$. brachypomus (Ribeiro et al. 2016). Nevertheless, P. brachypomus of the four fish farms had a moderate infection level of parasites. Monogeneans are the most frequent ectoparasites in farmed fish, due to their simple and direct life cycle that facilitates their reproduction in the cultivation environment, mainly when there is a low dissolved oxygen level in the tank water (Santos et al. 2013; Silva et al. 2013; Franceschini et al. 2013; Dias et al. 2015). In three of four fish farms, the dissolved oxygen levels were lower than $5.0 \mathrm{mg} / \mathrm{L}$, which is inadequate for fish production (Santos et al. 2013; Silva et al. 2013; Dias et al. 2015) and favors this parasitism. Hence, in the fish farm that had a good oxygen level, the infection rate by monogeneans was lower.

In fish populations, the host body provides a microhabitat for different taxa of parasite, thus the host size (age) can influence the parasites load. The body condition, a quantitative indicator of the degree of health and physical condition of fish, reflect the length-weight relationship of the individual, and this can be influenced by parasitism levels (Silva et al., 2013; Santos et al. 2013; Dias et al., 2015). The condition factor is a quantitative indicator of fish welfare and may serve as a tool for studying the relationship between host health and parasitism (Santos et al. 2013). There was a weak correlation of the abundance of $M$. viatorum and $A$. penilabiatus with the size (weight and length) of $P$. brachypomus, possibly due to the low size range of the examined hosts. Dias et al. (2015) reported a positive correlation of body size of the hybrid $C$. macropomum $x$ P. brachypomus with the abundance of Ichthyophthirius multifiliis, Piscinoodinium pillulare, monogeneans (Anacanthorus spathulatus, Linguadactyloides brinkmanni, Mymarothecium boegeri, Notozothecium janauachensis) and Perulernaea gamitanae. In addition, the moderate level of parasitism did not influence the relative condition factor of parasitized fish, as reported by Dias et al. (2015) for the hybrid C. macropomum x P. brachypomus.

Monogeneas are ectoparasites that can cause diseases to the host, leading to serious problems in fish farming due to their pathogenicity and low susceptibility to chemical therapeutic agents (Nakayasu et al. 2002). Anacanthus spathulatus is known for its pathogenicity, and may cause a decrease in the respiratory capacity of the host fish (Boeger and Viana 2006; Morais et al. 2009; Dias et al. 2015), depending on the parasitic abundance. In $P$. brachypomus, there was a predominance of $M$. viatorum, A. spathulatus and $A$. penilabiatus, which presented aggregated dispersion, a distribution pattern attributed to the strategy of reproduction of the parasites, as well as the heterogeneity of the immune system of hosts (Poulin 2013). Anacanthorus penilabiatus occurred only in two farms and at low infection levels, in contrast to what was reported for P. brachypomus farmed in the state of Ceará (Cohen and Kohn 2009). Only $M$. viatorum and $A$. spathulatus occurred in all four farms.

Echinorhynchus jucundus and Clinostomum marginatum occurred only in farm 3, both with low prevalence. Farm 3 was the only one supplying the tanks directly with water from natural water bodies, so this may have been the source of these parasites in the farm. Echinorhynchus jucundus is an acanthocephalan that infects $P$. brachypomus and Piaractus mesopotamicus Holmberg, 188 in Brazil (Santos et al. 2008). Acanthocephalan species are common in wild fish populations where there is a frequent presence of intermediate hosts of endoparasites with complex life cycles. Although the life cycle of E. jucundus is still unknown, in Echinorhynchidae in general it involves a crustacean isopod or amphipod as intermediate hosts, and fish as definitive hosts (Schmidt 1986; Aura et al. 2015). Despite its low infection level, the presence of $E$. jucundus should be monitored for necessary prevention and control measures, as this endoparasite can reduce the growth of farmed fish and cause production losses. The occurrence of metacercariae of $C$. marginatum also points to the presence of its intermediate host in the culture tanks, as Clinostomum species have a heteroxenous life cycle, and should also be monitored, as this digenean has zoonotic potential for humans (Bullard and Overstreet 2008).

Henneguya sp. cysts occurred only in farm 2, but in relatively high prevalence. These myxozoans are generally present in wild and farmed fish, and can cause diseases to the hosts when culture conditions are suboptimal (Martins et al. 2004). Under culture conditions, infections caused by myxozoans can be facilitated by the accumulation of organic matter and the presence of intermediate hosts (oligochaetes) on the bottom of the tanks (Franceschini et al. 2013).

\section{CONCLUSIONS}

Our results show that the parasitic prevalence in Piaractus brachypomus farmed in four fish farms in Acre state (western Brazilian Amazon) was influenced by the different management strategies of the farms, mainly in relation to fish stocking density and host age. The low dissolved oxygen level in the water of three farms likely contributed to the infection by monogeneans. The diversity of endohelminths was low, probably because they have a complex life cycle, which depends on the presence of intermediate hosts containing infective stages, which, when available in the cultivation environment, usually occur at low abundance. Our data on the frequency of occurrence and prevalence of parasites indicate the need to monitor parasite presence in local fish farms, and to adopt prophylactic measures to avoid economic losses due to potential outbreak of parasitic diseases in the future. We provide the first report on C. marginatum and Henneguya sp. for P. brachypomus. 


\section{ACKNOWLEDGMENTS}

M. Tavares-Dias receives a research fellowship (\# 303013/20150) from Conselho Nacional de Desenvolvimento Científico e Tecnológico - CNPq (Brazil). The authors thank the fish farmers for the supply of fish specimens used in this study.

\section{REFERENCES}

Aura, R.L.; Benesh, D.B.; Palomäki, R.; Valtonen, E.T. 2015. The natural history of Echinorhynchus bothniensis Zdzitowiecki and Valtonen, 1987 (Acanthocephala) in a high Arctic lake. Folia Parasitologica, 62: 051.

Boeger, W.A.; Viana, R.T. 2006. Monogenoidea. In: Thatcher, V.E (Ed.). Amazon Fish Parasites. Pensoft Publishers, Sofia-Moscow, p.42-116.

Bullard, S.A.; Overstreet, R.M. 2008. Digeneans as enemies of fishes. In: Eiras, J.C.; Segner, H.; Wahli, T.; Kapoor, B.G. (Ed.). Fish Diseases. v. 2. Science Publishers, Jersey, p.817-976.

Bush, A.O; Lafferty, K.D.; Lotz, J.M.; Shostak, W. 1997. Parasitology meets ecology on its own terms: Margolis et al. revisited. The Journal of Parasitology, 83: 575-583.

Cohen, S.C.; Kohn, A. 2009. On Dactylogyridae (Monogenea) of four species of characid fishes from Brazil. Check List, 5: 351-356.

Cruz, A.G.; Melo, A.E.E.F.; Sobreira, C.B.; Mazeto, M.D.; Naoe, L.K. 2006. Densidade x biomassa: piscicultura. Seagro Boletim Técnico, Palmas, 13p.

Dias, M.K.R.; Neves, L.R.; Marinho, R.G.B.; Pinheiro, D.A.; Tavares-Dias, M. 2015. Parasitismo em tambatinga (Colossoma macropomum x Piaractus brachypomus, Characidae) cultivados na Amazônia, Brasil. Acta Amazonica, 45: 231-238.

Eiras, J.C.; Takemoto, R.M.; Pavanelli, G.C. 2006. Métodos de estudos e técnicas laboratoriais em parasitologia de peixes. Eduem, Maringá, 199p.

FAO. 2018. The State of World Fisheries and Aquaculture 2018 - Meeting the sustainable development goals. Food and Agriculture Organization of the United Nations, Rome, 2010p.

Franceschini, L.; Zago, A.C.; Schalch, S.H.C.; Garcia, F.; Romera, D.M.; Silva, R.J. 2013. Parasitic infections of Piaractus mesopotamicus and hybrid (P. mesopotamicus x Piaractus brachypomus) cultured in Brazil. Revista Brasileira de Parasitologia Veterinária, 22: 407-414.

Kubitza, F.; Ono, E.A.; Campos, J.L. 2007. Os caminhos da produção de peixes nativos no Brasil: uma análise da produção e obstáculos da piscicultura projeto tanque-rede. Panorama da Aquicultura, 17: 14-23.

Le Cren, E.D. 1951. The length-weight relationship and seasonal cycle in gonadal weight and condition in the perch (Perca fluviatilis). Journal of Animal Ecology, 20: 201-219.

Ludwig, J.; Reynolds, J.F. 1988. Statistical ecology: a primer on methods and computing. Wiley-Interscience, New York, 337p.

Martins, M.L.; Onaka, E.M.; Bozzo, F.R.; Fenerick-Junior, J. 2004. Henneguya sp. (Myxozoa: Myxobolidae) in Pimelodus maculatus (Osteichthyes: Siluridae) from Volta Grande Reservoir, Minas Gerais, Brazil. Boletim do Instituto de Pesca, 30: 1-7.
Morais, A.M.; Varella, A.M.B.; Villacorta-Correa, M.A.; Malta J.C.O. 2009. A fauna de parasitos em juvenis de tambaqui Colossoma macropomum (Cuvier, 1818) (Characidae: Serrasalminae) criados em tanques-rede em lago de várzea da Amazônia central. Biologia Geral Experimental, 9: 14- 23.

Nakayasu, C.; Yoshinaga, T.; Kumagai, A. 2002. Hematology of anemia experimentally induced by repeated bleeding in Japanese flounder with comments on the cause of flounder anemia recently prevailing in Japan. Fish Pathology, 37: 125-130.

PeixeBR. 2019. Anuário PeixeBR da piscicultura 2019. Associação Brasileira da Piscicultura. (https://www.peixebr.com.br/anuariopeixe-br-da-piscicultura-2019/). Accessed on 26 Aug 2019.

Poulin, R. 2013. Explaining variability in parasite aggregation levels among host samples. Parasitology, 140: 541-546.

Ribeiro, F.M.; Freitas, P.V.D.X.; Santos, E.O.; Sousa, R.M.; Carvalho, T.A.; Almeida, E.M.; Santos, T.O.; Costa, A.C. 2016. Alimentação e nutrição de pirapitinga (Piaractus brachypomums) e tambaqui (Colossoma macropomum): Revisão. Pubvet, 10: 873-882.

Rohde, K.; Hayward, C.; Heap, M. 1995. Aspects of the ecology of metazoan ectoparasites of marine fishes. International Journal for Parasitology, 25: 945-970.

Rózsa, L.; Reiczigel, J.; Majoros, G. 2000. Quantifying parasites in samples of hosts. The Journal of Parasitology, 86: 228-232.

Saint-Paul, U. 2017. Native fish species boosting Brazilian's aquaculture development. Acta of Fisheries and Aquatic Resources, 5: 1-9.

Santos, C.P.; Gibson, D.I.; Tavares, L.E.R; Luque, J.L. 2008. Checklist of Acanthocephala associated with the fishes of Brazil. Zootaxa, 1938: 1-22.

Santos, E.F.; Tavares-Dias, M.; Pinheiro, D.A.; Neves L.R.; Marinho, R.G.B.; Dias, M.K.R. 2013. Fauna parasitária de tambaqui Colossoma macropomum (Characidae) cultivado em tanque-rede no estado do Amapá, Amazônia oriental. Acta Amazonica, 43: 107-114.

Schmidt, G.D. 1985. Development and life cycles. In: Crompton, D.W.T.; Nickol, B.B. (Ed.). Biology of the Acanthocephala. Cambridge University Press, Cambridge, p.273-286.

Silva, R.M.; Tavares-Dias, M.; Dias, M.W.R.; Dias, M.K.R.; Marinho, R.G.B. 2013. Parasitic fauna in hybrid tambacu from fish farms. Pesquisa Agropecuária Brasileira, 48: 1049-1057.

Tavares-Dias, M.; Martins, M.L. 2017. An overall estimation of losses caused by diseases in the Brazilian fish farms. Journal of Parasitic Diseases, 41: 913-918.

Verján, N.; Iregui, C.A., Rey, A.L.; Donado, P. 2001. Sistematización y caracterización de las lesiones branquiales de la cachama blanca (Piaractus brachypomus) de cultivo clínicamente sana: algunas interacciones hospedador-patógeno-ambiente. Revista Aquatic, 15: $1-15$.

Zar, J.H. 2010. Biostatistical analysis. $5^{\text {th }}$ ed. Prentice Hall, New Jersey, 944p.

\section{RECEIVED: $22 / 02 / 2019$ \\ ACCEPTED: 25/08/2019 \\ ASSOCIATE EDITOR: Linda Basson}

